\title{
Innovation and Shelf-Character: The Way of Organizational Existence in the Pandemic Era
}

\author{
Hendra Suwardana ${ }^{1}$ \\ Anggia Kalista ${ }^{2}$ \\ ${ }^{1,2}$ Fakultas Teknik Industri Universitas PGRI Ronggolawe Tuban \\ suwardanahendra@gmail.com
}

Coresponding Author: Hendra Suwardana; suwardanahendra@gmail.com

\begin{abstract}
ABSTRAK
Pandemi covid 19 menyadarkan pada tata piranti kehidupan organisasi sebagai entintas yang diyakini selama ini mapan, tapi sesungguhnya absurd. Kepastian itu hanya dimiliki bagi perubahan itu sendiri. Kemampuan beradaptasi terhadap lingkungan sekitar dengan mengadopsi nilai- nilai kearifannya yang tertuang dalam bentuk rangkaian inovasi secara berkelanjutan dapat menjamin eksistensi kehidupan organisasi untuk tumbuh dan berkembang sepanjang masa. Inovasi sebagai nilai investasi dapat tumbuh subur secara baik pada organisasi bilamana terdapat jiwa- jiwa kepemimpinan secara individu maupun secara hirarki kepemimpinan berjiwa terbuka dan memiliki kharakter diri yang kuat untu bersedia menerima masukan dari bawahan dan mampu mencermati perkembangan kekinian yang dibutuhkan pasar. Pada hari ini sebuah organisasi apabila tidak mau mengadopsi nilai inovasi sama halnya menuju jalan kematiannya secara lambat laun, sehingga pilihannya melakukan inovasi atau mati.
\end{abstract}

Kata Kunci: organisasi, inovasi, karakter diri.

\begin{abstract}
The Covid 19 pandemic has awakened the organizing of organizational life as an entity that is believed to be well established, but in fact absurd. This certainty belongs only to change itself. The ability to adapt to the surrounding environment by adopting its wisdom values which are contained in a series of continuous innovations can ensure the existence of organizational life to grow and develop throughout the ages. Innovation as an investment value can thrive both in an organization when there are leadership souls individually or in a hierarchical leadership that is open-minded and has a strong self-character to be willing to accept input from subordinates and be able to observe current developments that are needed by the market. On this day an organization if it does not want to adopt the value of innovation is the same as going to its death path slowly, so that the choice is to innovate or die.
\end{abstract}

Keywords: Organization, Inovation, Self Character

\section{INTRODUCTION}

The World is currently experiencing a period of uncertainty in all line sectors, both individually and in organizations. The size of the organization's scale faces the same challenges, namely the ability to exist with the characteristics of work productivity. The Covid-19 pandemic outbreak in 2019 is a phenomenal event as well as a fundamental turning point for the organization. In general, the world never imagined that this would happen and was only an illusion in film. The way the Covid-19 virus spreads like a zombie film can really make the "world stop".

During the Covid-19 pandemic, according to BPS data as of August 2020 the labor sector experienced a breakdown of work relations as many as 3.5 million people with a composition of $53 \%$ of productive age. Meanwhile, on the 
labor force side, there are also around 2.67 million people who are struggling to find work, so that the total unemployment rate is 9.77 million people (bps.go.id/2020).

The industrial organizations felt the most severe impact where the factors of production could not be carried out optimally. As sophisticated as any technology, an organizational entity really needs the presence of humans to solve its problems. Technology only makes it easier to solve problems, while humans are the subject of solving them. Direct interaction and communication as the most effective media to bring together many ideas stopped in this pandemic era which was replaced by telecommunication media with all its advantages and disadvantages.

The organizational culture in the pandemic era changes the form of something from the ordinary to the unusual. Healthy living standards become the main reference and eliminate a new belief system (dogma) that has been practiced so far. Changing these habits is not an easy matter, but a choice so that life continues. This is where the main challenge is for an organization to be able to maintain its existence as human beings.

The condition of stuttering in the face of a pandemic will be endless, because this pandemic will run from time to time with different patterns. Improving one's character (mind set) by innovating will be a turning point in the existence of a life with high productivity in any situation.

The real challenge is the ability to formulate and find patterns that uncertain situations are just forms created by thought opinions and weaken the critical power of finding solutions. In terms of every difficulty there will be convenience or every problem there must be a solution. Willingness and ability are the main assets in innovation. Anyone who cannot innovate is headed for the path of death. The existence of animal life can be maintained only when they are able to evolve / innovate in their environment.
The participation of stakeholders / all interested parties should sit together to find a breakthrough (innovation) that is adaptive and solution. Before discussing the big formula together, what must be done first is to rearrange one's own character in the ability to produce works in any condition and anywhere. If a pandemic condition will dull creativity, then what will happen is a big and complex problem for a nation and a country. Economic law has explained that factors of production can stop but consumption factors continue and will never stop.

The parameter of that existence is life by producing works of work. The working substance lies not in the place but on the output produced. Space and time are only categorizations that describe the place where you work and that too can be created anywhere to produce productivity.

Heathfield (2019) divides the types of work, which consist of working freely (flexi time) and full time (full time) (Oswar Mungkasa, The Indonesian Journal of Development Planning, 2020). Working freely can be interpreted as a work arrangement system that is given by the organization to a person to work independently and independently of his working hours. For the organization the most important thing is the result of its work on time. Meanwhile, full-time work emphasizes routines with a structured work schedule determined entirely by the organization

In principle, working freely or full time must adhere to bureaucratic values. The definition of bureaucracy is a chain of command system with the value of a clear division of labor tasks and has a hierarchical level of different responsibilities, so there is an expression that bureaucracy is the ideal type of officialdom. According to Max Weber (1947), bureaucracy is the most rational and imperative way of controlling people to work in a legally operational manner. The principle of bureaucracy consists of first, standardization; second formality; all three specialties; the 
fourth division of tasks; and fifth is documented. (Abdul Kadir, Journal of Unhas.ac.id 2005).

In awareness, the initial formulation of the mindset that needs to be changed is to interpret the bureaucracy as the sole owner (steorotype) in government. The essence of the bureaucracy can be adopted in a self-worth or standard in working either independently or in any institution. Self-awareness of understanding one's own abilities and knowing the stages of a job can be a pendulum of the ability to produce works.

The survey results of The Ministry of Finance Fitness Index (MOFIN) at the Indonesian Ministry of Finance in 2019 found a number of interesting new findings for organizations. One of them places the dimensions of Culture and Work Climate as a determinant factor for organizational health practices. There are three indicators used, namely; first, Operational Discipline Indicators; second, openness; and third, the Trust Indicator. (KEMENKEU Performance Bulletin Edition XXXIX / Semester I 2019).

This suggests that organizations need mutual confidence to clearly establish guidelines (guidence) on standards of behavior and performance, and exercise inherent oversight. The quality of interaction within the organization must uphold the values of honesty, transparency and open dialogue, resulting in an organizational culture that emphasizes results and outcomes.

The atmosphere of the organization creates a climate of internal competition that is healthier and can foster a spirit of creativity and entrepreneurship. In the long run, it can erode some of the habits that have become culture and hegemony into bureaucratic and "ewuh pakewuh" characteristics, and the lack of attention from the leadership. In fact, the dimension of motivation has always been a dimension considered important for organizational progress. Measures of the motivation dimension can be seen from career opportunities, financial incentives, and rewards.

\section{METHODE \\ Research Design}

The data in this study are literature review

\section{RESULTS AND DISCUSSION}

The impact of the Covid-19 pandemic storm marked the pinnacle of the continuity of the era of information technology on all fronts. The end of the 20th century actually with the discovery of a variety of communication technologies and the internet made hopes for the development of remote work systems. The ability to change the activity pattern of the working system is in fact unable to answer completely. There are many challenges that must be faced in the remote working system even though the infrastructure is adequate. The main challenge is that human nature is a social creature, said Philosophy Aristotle and in the sociology of social beings is an ideological concept in which humans are called living organisms (Johny Purba, 2005).

The many countries that have adopted either direct or remote work systems each display their advantages and disadvantages. In general, in general, direct work is still the best choice, even though it has been helped by the ease of communication technology. If it is further described the strengths and weaknesses of remote working systems from various dimensions and perspectives of stakeholders, it will be illustrated as follows.

Original contributions are solicited on topics covered under broad areas such as (but not limited to): electrical engineering, information technology, and accounting.

Table 1: Advantages and Weaknesses Work in Office and Work from Home

\begin{tabular}{|l|l|l|l|l|}
\hline No & Dimension & Perspective & Benefit & weakness \\
\hline 1 & $\begin{array}{l}\text { Economic- } \\
\text { Management }\end{array}$ & Employee & $\begin{array}{l}\text { 1. Independent } \\
\text { 2. Flexibility of work } \\
\text { schedules }\end{array}$ & $\begin{array}{l}\text { 1. Limited direct transfer of } \\
\text { knowledge } \\
\text { 2. Limited interaction and }\end{array}$ \\
\hline
\end{tabular}




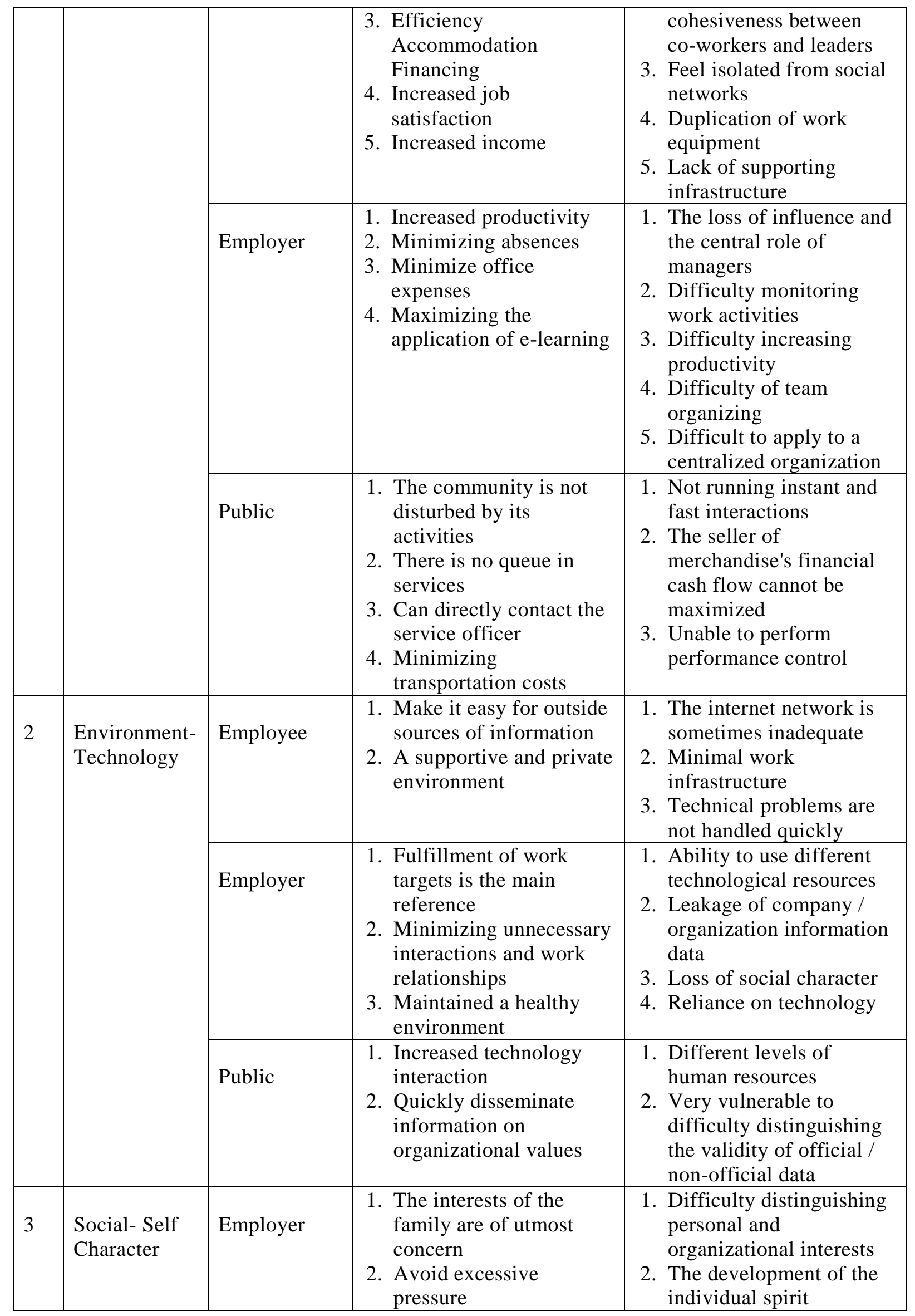




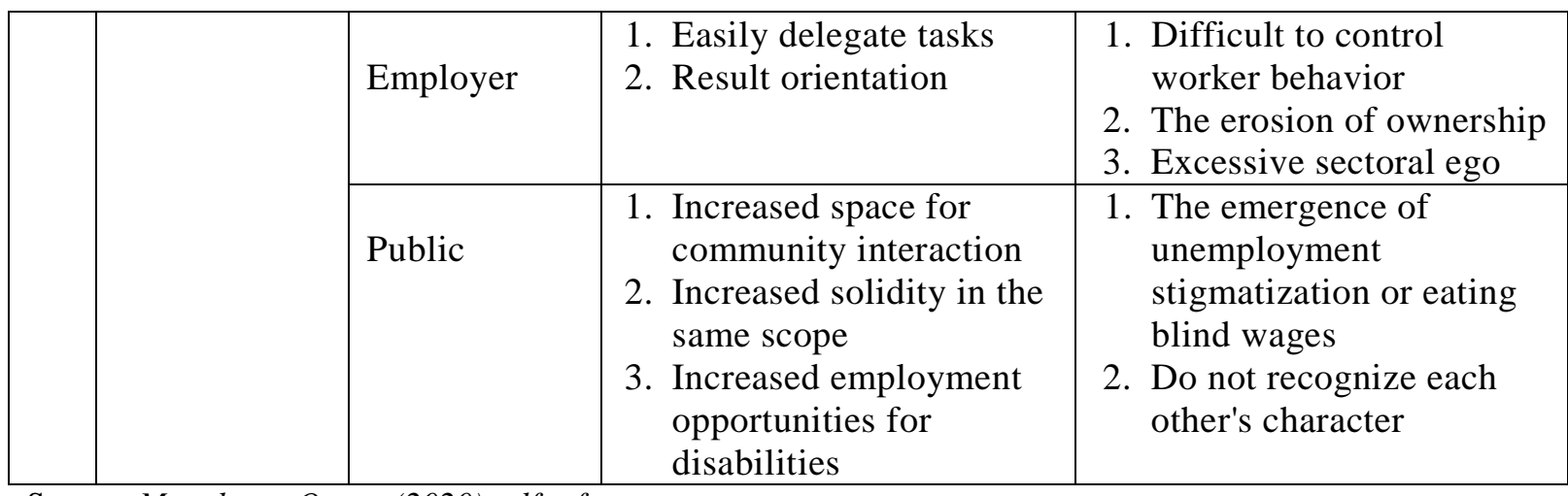

Source: Mungkasa, Oswar (2020) self references

\section{CONCLUSION}

Changes in the surrounding environment are so fast that they become new challenges as well as threats for an organization to immediately adapt to a productive and optimal performance. Organizational success is determined by the extent of adaptability (Ancok, 2012).

This is where all needs innovation in order to survive and continue it in a better direction. The greatest demand from the managers of the organization is to become a learning organization. According to Senge, 2006 learning organization is defined as an organization that continuously develops sustainable capacity by always maintaining or redefining the way of thinking of seeing an object or subject itself both individually and collegially.

The most prominent characteristic that can be found from the type of organization above is that the managers of the organization have an open self-character, always increase motivation and work as a team. Organizational culture and values that are habitual become challenges in itself for innovation (Fry, 2003). The ability and willingness of leadership can be the fastest way for the birth and flourishing of innovation. The results showed that transformational leadership with a proactive personality and work design simultaneously was able to increase the innovation behavior of organizational members (Iffah, Fathul, 2018).
Innovation is believed to be a way of realizing organizational success and innovation as a way for organizations to develop results and provide excellent service to the surrounding environment (Schermuly, et al, 2013). Imran Saeed, et, al., 2010 found that in order to survive or be able to remain competitive in the digital era of technology, every company is determined by the results of innovation in the form of new ideas of its members to meet market needs. The results also show that $80 \%$ of the new ideas are found by members of the organization and only $20 \%$ of the results of the innovation plans established by the organization, Getz and Robinson, 2003.

Arum Etikariena, 2018 describes the results of his research on innovative work behavior based on individual employee characteristics. These individual characteristics can be seen from age, gender, education, ethnicity, length of work and position. The results showed that individual characteristics in the form of age, education, years of service and position were significant for innovative work behavior. While attributive ethnicity, gender has no effect. So that it can be drawn a common thread, that if every organization wants to have a lot of innovation obtained by members of the organization, it must consider the factors of individual character above which have very strong significance. Notes that can be obtained if the organization does not consider the above, then in fact the wheels of the organization lead 
to life and do not want to, and even die are reluctant.

\section{REFERENCES}

Ancok, D, (2012). Psikologi Kepemimpinan dan Inovasi. Jakarta: Erlangga

Etikariena, Arum, (2018). Perbedaan Perilaku Kerja Inovatif Berdasarkan Karakteristik Individu Karyawan. Jurnal Psikologi UNDIP, Vol 17 no 2 Oktober 2018, 107118: Semarang

Fitri, Iffah, Himam, Fathul, (2018). Kepemimpinan Transformasional, Kepribadian proaktif dan Desain Kerja sebagai Prediktor Perilaku Kerja Inovatif, 2018. Gadjah Mada Journal of Psychology (GAJAMOP) Volume 4, No 2, 2018: Yogyakarta

Fry, L, W, (2003). Toward a Theory of Spiritual Leadership. The Leadership Querterly, 14(6), 693727.doi:10.1016/j.leaqua.2003.09.001

Getz, Robinson, 2003. Innovate or Die: Is That a Fact? Creativity and Innovation Management, 12(3), 130-136. https://doi.org?10.1111/1467-8691.00276

Imran, R, Saeed, T, (ed), (2010). Organizational Climate as a Predictor of Innovative Work Behavior. African Journal of Business Management, 4(15), 333733343

Inovasi di Tengah Pandemi; Buletin Kinerja KEMENKEU Edisi XXXIX/Semester I 2019

Kadir, Abdul, (2005). Prinsip-Pprinsip dasar Rasionalisasi Birokrasi Max Weber. Jurnal Unhas.ac.id Jumlah pengangguran Tahun 2020. Bps.go.id

Purba, Jhony, (2005). Pengelolaan Lingkungan Sosial. Yayasan Obor Indonesia; Yogyakarmungkasa, Oswar, 2020. The Indonesian Journal of Development Planning Volume IV No 2. Journal.bappenas. go.id

Schermuly, C.C, Meyer, B\&Dammer, L, (2013). Leader-Member Exchange and Innovative Behavior. The Mediating Role of Psychological Empowerment. Journal of Personal Pschology, 12(3), 132-142

Senge, P.M, (2006). The Fifth Discipline: The Art and Practice of The Learning
Organization. New York: Curruncy Doubleday 